\title{
Correction to: Towards estimating the economic cost of invasive alien species to African crop and livestock production
}

\author{
René Eschen ${ }^{1 *} \mathbb{0}$, Tim Beale ${ }^{2}$, J. Miguel Bonnin ${ }^{3}$, Kate L. Constantine ${ }^{3}$, Solomon Duah ${ }^{4}$, Elizabeth A. Finch ${ }^{3}$, \\ Fernadis Makale ${ }^{5}$, Winnie Nunda ${ }^{5}$, Adewale Ogunmodede ${ }^{3}$, Corin F. Pratt ${ }^{3}$, Emma Thompson ${ }^{3}$, \\ Frances Williams ${ }^{5}$, Arne Witt ${ }^{5}$ and Bryony Taylor ${ }^{3}$
}

\section{Correction to: CABI Agric Biosci (2021) 2:18 https://doi.org/10.1186/s43170-021-00038-7}

Eschen et al. (2021) estimated the annual cost of invasive alien species (IAS) to African agriculture, separated into the cost due to yield loss, the cost of weeding, the loss of livestock-based income and the cost of research. The paper revealed the vast cost of IAS to the continent and estimated the total cost to be USD $3.66 \mathrm{Tn}$, with by far the largest part of the estimated cost (USD 3.63 Tn) due to weeding. The study concluded that there is a need for pre-emptive measures to reduce future costs, as well as measures that contribute to the control of widely established IAS to reduce losses and improve livelihoods.

After publication, it was brought to our attention that the estimated cost of weeding was much higher than can reasonably be expected although the input data and general approach to calculating the estimate were not disputed. We therefore revisited our calculations and found a scaling error that occurred during the application of wages to the harvested area for each of the five crop types. As described in the original article, we calculated

The original article can be found online at https://doi.org/10.1186/s43170021-00038-7.

${ }^{*}$ Correspondence: r.eschen@cabi.org

'CABI, Delémont, Switzerland

Full list of author information is available at the end of the article the cost of weeding IAS in five crop types based on the harvested area in each African country, calculated from data in the SPAM database, the average abundance of alien species as a fraction of the weed community in African agricultural fields as deducted from the published literature. The average time spent weeding a hectare of each of the five crop types was taken from the published literature, and wages paid in each country for agricultural labour or similar jobs as reported on https://wagecalcul ator.org. We erroneously applied costs per square kilometre instead of the cost of weeding per hectare, resulting in substantially overestimated weeding costs. The calculations of the estimates of yield loss, the loss of livestock-based income and research costs were not affected by this error.

Table 3 The absolute and relative contribution of labour, yield loss, lost livestock derived income and research to the annual cost of IAS to African agriculture in billions USD

\begin{tabular}{lcc}
\hline Damage component & \multicolumn{2}{c}{ Annual cost contribution in } \\
\cline { 2 - 3 } & USD & Percentage \\
\hline Yield loss & 29.06 & 44.31 \\
Weeding & 36.34 & 55.42 \\
Lost livestock derived income & 0.17 & 0.26 \\
Research & 0.00 & 0.00 \\
Total & 65.58 & \\
\hline
\end{tabular}

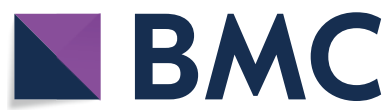

(c) The Author(s) 2021. Open Access This article is licensed under a Creative Commons Attribution 4.0 International License, which permits use, sharing, adaptation, distribution and reproduction in any medium or format, as long as you give appropriate credit to the original author(s) and the source, provide a link to the Creative Commons licence, and indicate if changes were made. The images or other third party material in this article are included in the article's Creative Commons licence, unless indicated otherwise in a credit line to the material. If material is not included in the article's Creative Commons licence and your intended use is not permitted by statutory regulation or exceeds the permitted use, you will need to obtain permission directly from the copyright holder. To view a copy of this licence, visit http://creativecommons.org/licenses/by/4.0/. The Creative Commons Public Domain Dedication waiver (http://creativeco mmons.org/publicdomain/zero/1.0/) applies to the data made available in this article, unless otherwise stated in a credit line to the data. 


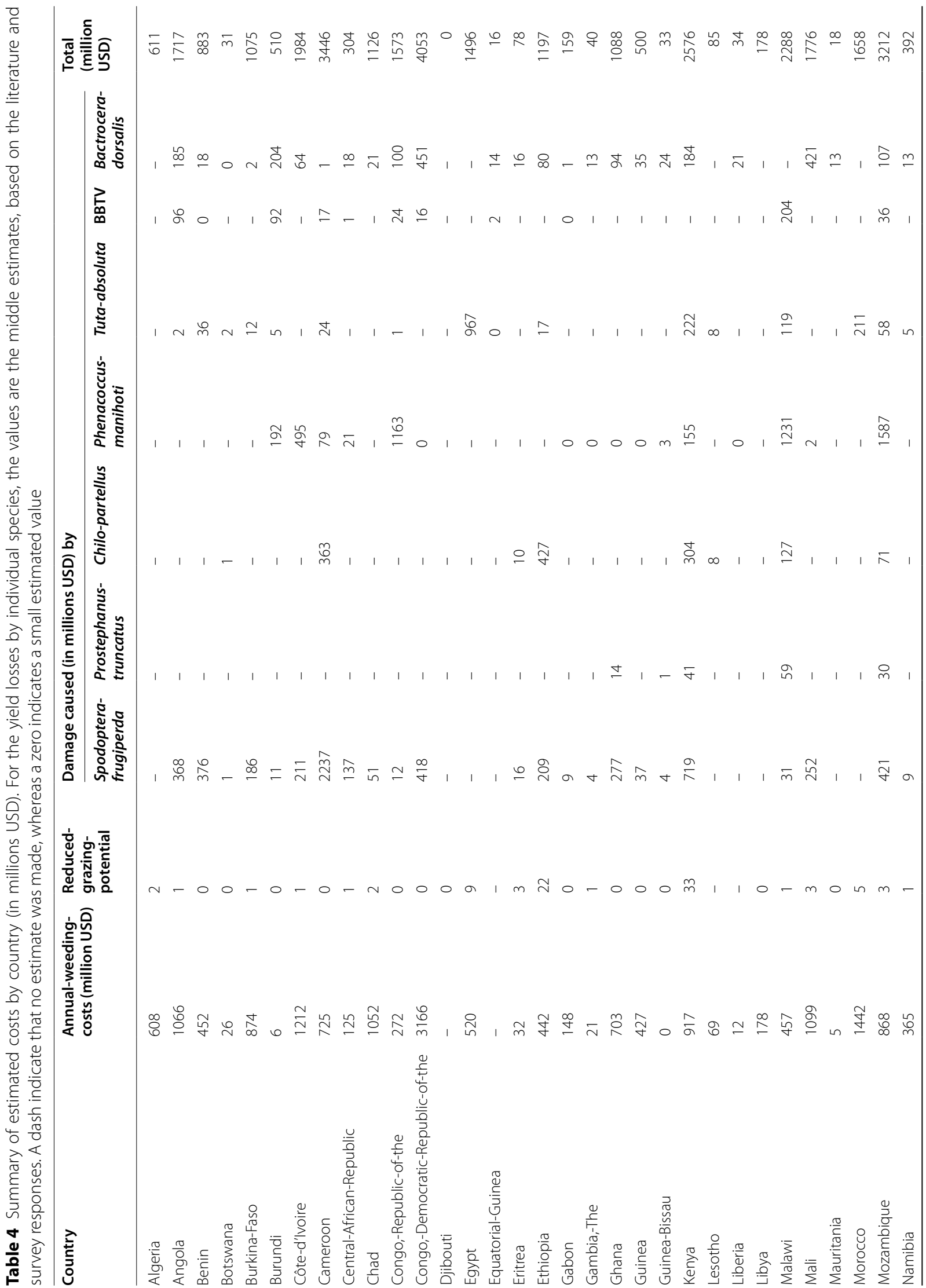




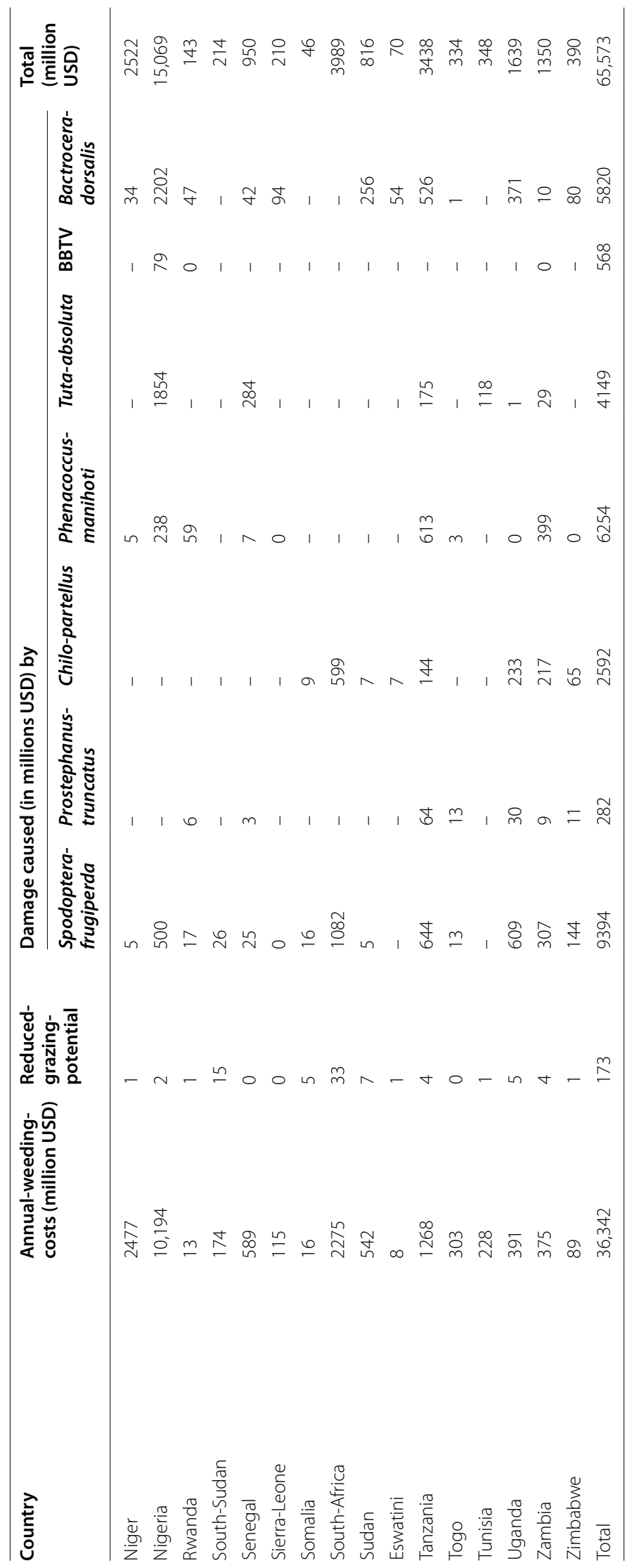


Table 5 Estimated yield loss caused by individual IAS in Africa

\begin{tabular}{lllr}
\hline Host plant & IAS & \multicolumn{2}{l}{ Yield loss values (billions USD) estimated by } \\
\cline { 3 - 4 } & & Literature only & Literature+ survey \\
\hline Maize & Spodoptera frugiperda & $6.9(-)^{*}$ & $9.4(7.7-12.1)$ \\
& Prostephanus truncatus & $0.2(0.1-0.3)$ & $0.3(0.2-0.5)$ \\
& Chilo partellus & $2.6(2.1-3.1)$ & $2.6(2.1-3.1)$ \\
Cassava & Phenacoccus manihoti & $0.0(0.0-0.0)$ & $6.3(5.5-7.3)$ \\
Tomato & Phthorimaea absoluta & $4.8(3.6-6.7)$ & $4.1(3.2-5.6)$ \\
Banana & BBTV & $0.2(-)$ & $0.6(0.5-0.6)$ \\
Mangoes (and citrus in survey) & Bactrocera dorsalis & $3.5(1.7-10.6)$ & $5.8(4.4-10.0)$ \\
Total & & 18.2 & 29.1 \\
\hline
\end{tabular}

* Numbers in brackets indicate high and low estimates

We corrected this error in our calculations and have updated the results, specifically Table 3 , which presents to total estimate, and Table 4, which presents the estimates for each country. These corrected Tables are presented here. We have updated the numbers stated in the Abstract and in the Results section of the manuscript text to reflect the corrected results. We also modified the discussion where these estimates are put into context. While the total estimate of IAS cost to African agriculture are now significantly lower, the conclusions and recommendations have not changed.

We have also corrected the value for the yield loss due to Phthorimaea absoluta based on the literature and a survey in Table 5. The value in the previous version of the manuscript was wrong due to a transcription error. The new value is corrected for abundance within each country, like the other values in the Table. This species was deleted from the abstract as the most costly species and minor changes to the Results and Discussion were made to align the text with the correct number. A reference made to an article 'in press' during publication has also been updated with the article's final reference detail.
We apologise for the errors and any confusion they may have caused.The original article has been updated.

\section{Author details}

${ }^{1} \mathrm{CABI}$, Delémont, Switzerland. ${ }^{2} \mathrm{CABI}$, Wallingford, UK. ${ }^{3} \mathrm{CABI}$, Egham, UK. ${ }^{4} \mathrm{CABI}$, Accra, Ghana. ${ }^{5} \mathrm{CABI}$, Nairobi, Kenya.

Published online: 19 August 2021

\section{Reference}

Eschen R, Beale T, Bonnin JM, Constantine KL, Duah S, Finch EA, Makale F, Nunda W, Ogunmodede A, Pratt CF, Thompson E, Williams F, Witt A, Taylor B. Towards estimating the economic cost of invasive alien species to African crop and livestock production. CABI Agric Biosci. 2021;2(2):18. https:// doi.org/10.1186/s43170-021-00038-7.

\section{Publisher's Note}

Springer Nature remains neutral with regard to jurisdictional claims in published maps and institutional affiliations.
Ready to submit your research? Choose BMC and benefit from:

- fast, convenient online submission

- thorough peer review by experienced researchers in your field

- rapid publication on acceptance

- support for research data, including large and complex data types

- gold Open Access which fosters wider collaboration and increased citations

- maximum visibility for your research: over $100 \mathrm{M}$ website views per year

At BMC, research is always in progress.

Learn more biomedcentral.com/submissions 